London

Cite this as: $B M J$ 2021;372:n148 http://dx.doi.org/10.1136/bmj.n148 Published: 15 January 2021

\title{
Covid-19: Government uses lateral flow tests to keep children in schools against regulator's advice
}

Jacqui Wise

The UK government has confirmed that it is using daily contact testing in schools as an alternative to self-isolation as part of an "ongoing evaluation," even though the UK regulator has not approved antigen lateral flow devices to be used this way.

However, schools have not been informed that they are part of such an evaluation, and no informed consent or appropriate data collection processes are in place.

Experts have repeatedly raised concerns about the accuracy of the Innova tests and warned that using them to manage classroom outbreaks without isolating close contacts risks increasing the spread of the virus. ${ }^{1-3}$

A handbook for schools and colleges issued on 4 January says that pupils, students, and staff will be tested daily if they come into contact with a positive case. ${ }^{4}$ It says that this will allow those who are in close contact with someone who has tested positive for covid-19 to return to school or college if they agree to be tested for seven days after their last contact with a positive case. It does not say that this is part of an evaluation, and schools have not received any updated guidance on this.

However, the Guardian newspaper has revealed that the Medicines and Healthcare Products Regulatory Agency (MHRA) told the Department of Health and Social Care on 12 January that it had not approved lateral flow kits for daily contact testing because of concerns that they give people false reassurance if they are negative. This could lead to pupils staying in school and potentially spreading the virus when they should be self-isolating. ${ }^{5}$

\section{Asymptomatic cases}

In December the MHRA issued an exceptional use authorisation allowing the Innova test to be used as a self-test device to detect asymptomatic people-known as "test to find." People with a positive test would then be asked by NHS Test and Trace to isolate and to confirm the result with a polymerase chain reaction (PCR) test. ${ }^{6}$

An MHRA spokesperson told The BMJ, “The Innova test can be used under trained supervision in a school setting, which means that the test is being used within the manufacturer's intended purpose. We have provided NHS Test and Trace with some considerations that they need to take account of when deploying tests in this way-including undertaking a risk assessment-but it is not subject to our approval."

However, the spokesperson confirmed, "The MHRA has not issued an exceptional use authorisation for that self-test device for 'serial testing' for school pupils who have been exposed to a confirmed positive covid case that would enable them to attend school as normal. MHRA continues to advise that close contacts of positive cases identified using the self-test device continue to self-isolate in line with current guidelines. Discussions with Test and Trace regarding any future exceptional use cases are ongoing."

Jon Deeks, professor of biostatistics at the University of Birmingham and leader of the Cochrane Collaboration's covid-19 test evaluation activities, told The BMJ, "This clarification from the MHRA is very welcome-that they have not approved this lateral flow test as a test-to-enable-such as repeated testing of contacts in classrooms, or any situations where negative results allow an activity which otherwise would not happen. This is in line with the available science."

He added, "The statement that use in close contacts is part of a study will be news to schools, pupils, parents, and teachers, none of whom have been informed or consented. Nor is a protocol available with evidence of appropriate ethical approval for a study in children. Given that the policy is contrary to MHRA advice, these are all required."

\section{Chains of transmission}

A Department of Health and Social Care spokesperson said, "The MHRA has not refused to approve rapid testing in schools. Lateral flow devices are a vital tool to finding more asymptomatic cases, and the government's approach to testing in schools will reduce transmission.

"We are testing teachers and students weekly on site to find positive cases and break the chains of transmission. In addition, as part of an ongoing evaluation, we are doing daily contact testing in schools using an assisted testing model."

The department said that the process for the design of daily contact testing had been comprehensive and successfully implemented in 12 pilot schools and colleges in England and a further two schools in Northern Ireland. An additional 14 pilots have been led by Public Health England and the city of Liverpool. The department did not respond when asked whether daily contact testing would now take place outside these pilots. It has also not produced any information to indicate whether the pilots looked at the effects of the scheme on virus transmission or on safety.

The government has spent at least £1.5bn ( $€ 1.7 \mathrm{bn}$; $\$ 2$ bn) on the lateral flow devices, which have been used by universities, care homes, and hospitals. On 15 December daily testing was touted as a central part of the government's plan to get all students back to 
teaching face to face. ${ }^{7}$ The tests are already being used in schools that are open to children of key workers and other vulnerable groups, and no updated guidance has yet been given.

Paul Whiteman, general secretary of the National Association of Head Teachers, said, "The suggestion that the MHRA have not approved these tests to be used as an alternative to self-isolation is alarming, as that is precisely what the government are suggesting schools should do as part of their testing strategy. The government also needs to urgently explain why it took such an approach if the MHRA approval was not in place.”

Deeks added, “The government are making a mistake. Without a sound scientific basis, the government are putting children, teachers, and families at risk. It must stop.”

1 Wise J. Covid-19: Safety of lateral flow tests questioned after they are found to miss half of cases. BMJ2020;371:m4744. doi: 10.1136/bmj.m4744 pmid: 33277265

2 Mahase E. Covid-19: Innova lateral flow test is not fit for "test and release" strategy, say experts. BMJ 2020;371:m4469doi: 10.1136/bmj.m4469.

3 Deeks J, Gill M, Bird S, et al. Covid-19 Innova testing in schools: don't just test, evaluate. BMJ Opinion 2021 Jan 12. https://blogs.bmj.com/bmi/2021/01/12/covid-19-innova-testing-in-schoolsdont-just-test-evaluate/?utm_source=feedburner\&utm_medium=feed\&utm_campaign=Feed\%3A+bmj\%2Fblogs+\%28Latest+BMJ+blogs\%29\&g=w_bmj-com.

$4 \quad$ NHS Test and Trace. Covid-19 National Testing Programme: Schools and College Handbook. 15 Dec 2020. https://assets.publishing.service.gov.uk/government/uploads/system/uploads/attachment_data/file/950515/Schools_Colleges_Testing_Handbook_revised_04012021.pdf.

5 Regulator refuses to approve mass daily Covid testing at English schools. Guardian 2021 Jan 15 https://www.theguardian.com/world/2021/jan/14/regulator-refuses-to-approve-mass-covidtesting-schools-in-england?CMP=Share_iOSApp_Other.

6 Medicine and Healthcare Products Regulatory Agency. MHRA issues exceptional use authorisation for NHS Test and Trace COVID-19 Self-Test device. 23 Dec 2020. https://www.gov.uk/government/news/mhra-issues-exceptional-use-authorisation-for-nhs-test-and-trace-covid-19-self-testdevice.

7 Department for Education. Department of Health and Social Care, Williamson G. Secondary schools and colleges to get weekly coronavirus testing. 15 Dec 2020. https://www.gov.uk/government/news/secondary-schools-and-colleges-to-get-weekly-coronavirus-testing.

This article is made freely available for use in accordance with BMJ's website terms and conditions for the duration of the covid-19 pandemic or until otherwise determined by BMJ. You may use, download and print the article for any lawful, non-commercial purpose (including text and data mining) provided that all copyright notices and trade marks are retained. 